\title{
The Sharing of the Same Host of Two Species of Anemonefish in the Gulf of Thailand, One of Which Is Possibly Introduced
}

\author{
Se Songploy ${ }^{1,2}$, Suchana Chavanich ${ }^{1, *} \mathbb{0}$, Yosuva Mariasingarayan ${ }^{1}$ and Voranop Viyakarn ${ }^{1}$ \\ 1 Reef Biology Research Group, Department of Marine Science, Faculty of Science, Chulalongkorn University, \\ Bangkok 10330, Thailand; Se.s@chula.ac.th (S.S.); yosuva.m@chula.ac.th (Y.M.); voranop.v@chula.ac.th (V.V.) \\ 2 Aquatic Resources Research Institute, Chulalongkorn University, Bangkok 10330, Thailand \\ * Correspondence: suchana.c@chula.ac.th; Tel.: +66-2-218-5394; Fax: +66-2-255-0780
}

Keywords: anemonefish; Thailand; habitat; reef; coexisting

check for

updates

Citation: Songploy, S.; Chavanich, S.; Mariasingarayan, Y.; Viyakarn, V. The Sharing of the Same Host of Two Species of Anemonefish in the Gulf of Thailand, One of Which Is Possibly Introduced. Diversity 2021, 13, 304. https://doi.org/10.3390/d13070304

Academic Editors: Bert W. Hoeksema, Ku'ulei Rodgers and Keisha Bahr

Received: 14 May 2021

Accepted: 1 July 2021

Published: 5 July 2021

Publisher's Note: MDPI stays neutra with regard to jurisdictional claims in published maps and institutional affiliations.

Copyright: (c) 2021 by the authors Licensee MDPI, Basel, Switzerland. This article is an open access article distributed under the terms and conditions of the Creative Commons Attribution (CC BY) license (https:// creativecommons.org/licenses/by/ $4.0 /)$
At Samaesan Island, which is in Chon Buri Province, the Upper Gulf of Thailand, in 2018 we found skunk anemonefish (Amphiprion akallopisos) previously only known from the Andaman Sea that have been establishing their populations in the area at a 4-m depth. We also observed this anemonefish sharing the same magnificent sea anemone (Heteractis magnifica) with another local pink anemonefish (A. perideraion) [1]. The coexistence in the same habitat of two anemonefish species has never been reported before in Thailand (Figure 1). However, the sharing of the same sea anemone was earlier reported in Indonesia [2,3] and Philippines [4].

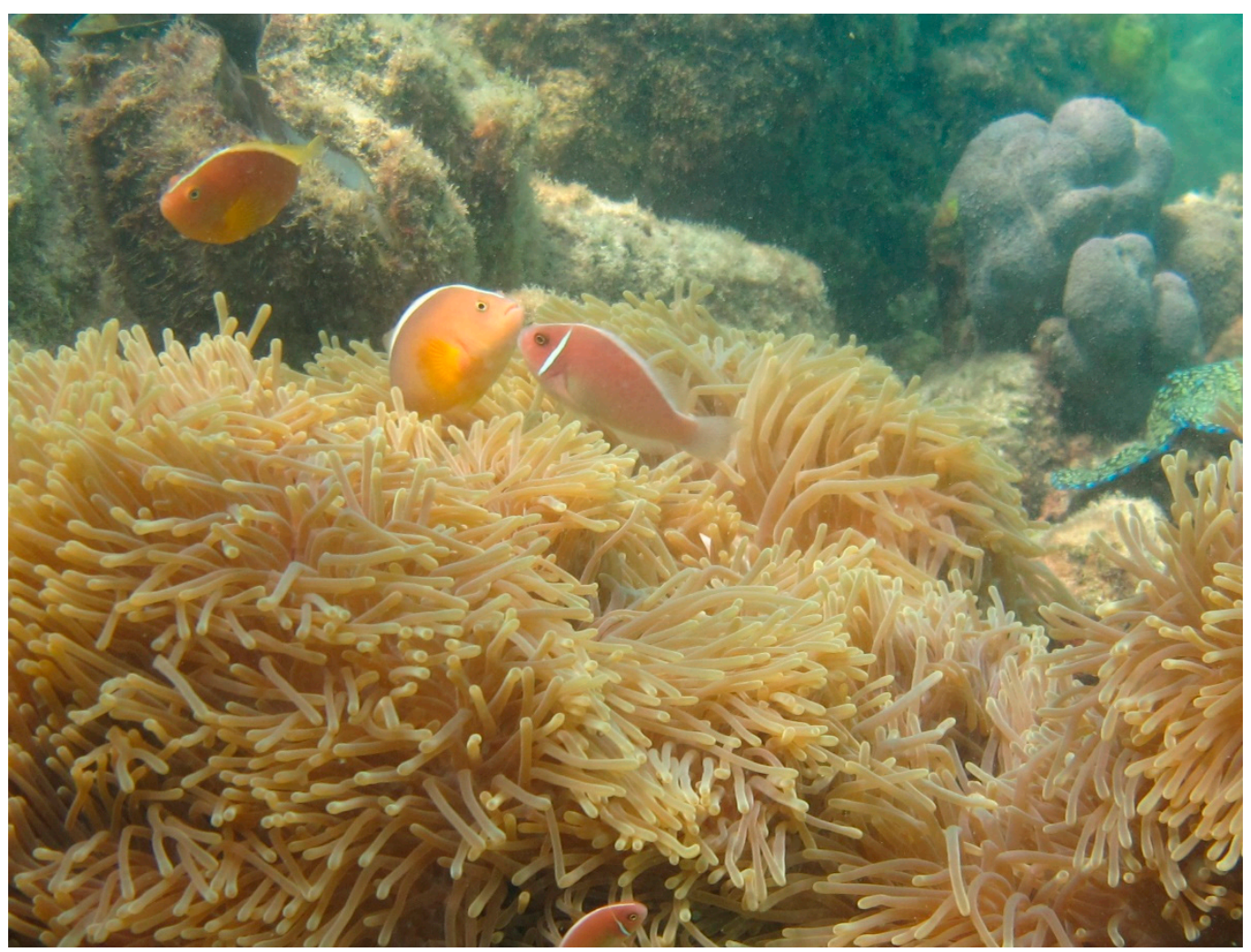

Figure 1. Skunk anemonefish (Amphiprion akallopisos) and pink anemonefish (Amphiprion perideraion) sharing the magnificent sea anemone. The primary difference in coloration between skunk and pink anemonefish is the vertical white head bar behind the eye of the latter species. 
How these introduced skunk anemonefishes were able to move from the Andaman Sea to the upper Gulf of Thailand is unknown. The Gulf of Thailand and the Andaman Sea are separated by the Malay Peninsula, which is composed of three countries, Myanmar, Thailand, and Malaysia. As the Malay Peninsula partially divides the Gulf of Thailand and the Andaman Sea, the movement of marine species between these locations is unlikely. Previous study showed that only two species of anemonefish, A. perideraion and A. polymnus, were found in the Gulf of Thailand [5]. We suspect that the skunk anemonefish were intentionally introduced and released to the natural reefs in the Gulf of Thailand through corporate social responsibility (CSR) activities (personal observations). At present, skunk anemonefish can be cultured for aquarium purpose, and thus, Thai people have been using this skunk anemonefish for CSR activities. Since corporate social responsibility aims to integrate social and environmental concerns into the company business and have interaction with stakeholders for positive social value, releasing species back to the sea can fulfill their responsibility towards nature.

Normally, anemonefish show territorial behaviors toward intruders and divers [6]. Therefore, the co-existence between two anemonefishes within the same sea anemone can be influenced by the environments and the limitation of the habitats $[7,8]$. However, more studies are needed to provide insight into the persistence of this interspecific relationship and the biological consequences it may have for individuals.

Author Contributions: Conceptualization, S.S., S.C. and V.V.; identification, S.S. and S.C.; validation, S.S. and S.C.; investigation, S.S., S.C. and V.V.; writing-review and editing, S.S., S.C., Y.M. and V.V.; project administration, S.C.; funding administration, S.C. and V.V. All authors have read and agreed to the published version of the manuscript.

Funding: The funding was provided by Postdoctoral scholarship of Chulalongkorn University, NRCT-JSPS Core to Core Program, and Mubadala Petroleum (Thailand) Limited.

Institutional Review Board Statement: Not applicable.

Informed Consent Statement: Not applicable.

Data Availability Statement: Not applicable.

Acknowledgments: This work was supported by the Plant Genetic Conservation Project under the Royal Initiative of Her Royal Highness Princess Maha Chakri Sirindhorn and the Naval Special Warfare Command, the Royal Thai Navy.

Conflicts of Interest: The authors declare no conflict of interest.

\section{References}

1. Fautin, D.G.; Allen, G.R. Field Guide to Anemonefishes and Their Host Sea Anemones; Western Australian Museum: Perth, Australia, 1992; pp. 1-65.

2. Kuiter, R.H.; Tonozuka, T. Pictorial Guide to Indonesian Reef Fishes; Zoonetics: Seaford, Australia, 2001.

3. De Brauwer, M.; Camp, E.; Jompa, J.; Smith, D.J. High levels of heterospecific cohabitation among anemonefishes in Hoga Island, Indonesia. Mar. Biodivers. 2015, 46, 19-20. [CrossRef]

4. Bos, A.R. Clownfishes Amphiprion clarkii and A. sandaracinos (Pomacentridae) coexist in the sea anemone Stichodactyla mertensii. Coral Reefs 2011, 30, 369. [CrossRef]

5. Satapoomin, U. A preliminary checklist of coral reef fishes of the Gulf of Thailand, South China Sea. Raffles Bull. Zool. 2000, $48,31-53$.

6. Moyer, J.T. Anemonefishes of the World; TBS-Britanica Co., Ltd.: Tokyo, Japan, 2001.

7. Hattori, A. Small and large anemonefishes can coexist using the same patchy resources on a coral reef, before habitat destruction. J. Anim. Ecol. 2002, 71, 824-883. [CrossRef]

8. Camp, E.F.; Hobbs, J.-P.A.; De Brauwer, M.; Dumbrell, A.J.; Smith, D.J. Cohabitation promotes high diversity of clownfishes in the Coral Triangle. Proc. R. Soc. B Biol. Sci. 2016, 283, 20160277. [CrossRef] [PubMed] 